\title{
SEKERE ASPEKTE VAN DIE SUID-AFRIKAANSE EKONOMIE
}

My vak, naamlik Staathuishoudkunde, se oorspronklike benaming was „politieke ekonomie". Dit is baie jammer dat ons dit nie meer ter harte neem nie, en dat ons so dikwels vind dat ons die politiek het sonder die ekonomie, en ewe dikwels die ekonomie sonder die ploitiek: die een gebrek kan so sleg wees soos die ander wat die welvaart van 'n land betref. Waar die politieke leiers van 'n volk dus die kennis van ekonomie as iets van minder belang beskou in 'n wêreld waar byna alles om die ekonomie draai, kan onberekenbare skade aan die voortbestaan en groei van 'n volk berokken word; en die teenoorgestelde is ook waar: waar' $n$ ekonoom sy vak, en die toepassing daarvan, uit die standpunt van die abstrakte teorie beskou, afgesien van sy land se politieke omstandighede, kan hy 'n dodelike gevaar vir land en 
volk wees. Ekonomiese beginsels is verder nie absolute waarhede wat onveranderd bly deur alle tye en onder alle omstandighede nie, en as ekonome dikwels in onguns raak by die publiek dan is dit te wyte aan die feit dat hulle hierdie eenvoudige waarheid ignoreer. Die staathuishoudkunde kan eenvoudig nooit 'n eksakte wetenskap wees nie, omdat dit te doen het met die gedurige maatskaplike veranderings wat die tyd en ander omstandighede (soos woonplek, volksaard, natuurlike potensialiteite, ens.) meebring.

In hierdie opsig behoort die Afrikaanse ekonoom veral op sy hoede te wees, vandag meer as ooit tevore. Ek dink ek is reg as ek sê dat die eerste leerstoel in die staathuishoudkunde in Suid-Afrika in 1913 ingestel is aan die South African College, toe professor Leslie aangestel is. Later is professor Lehfeldt aan die Johannesburgse Universiteitskollege aangestel. Beide hierdie professore was deurtrek met die idees van die sogenaamde Britse klassieke skool van politieke ekonomie, terwyl Suid-Afrikaanse studente, wat hulleself in die vak gekwalifiseer het, in dieselfde skool georiënteer is. En wat is die basis van die Britse klassieke skool van politieke ekonomie? Dit naamlik, dat as elke indiwidu sy eie belang volg dan bevorder hy daardeur, asof deur 'n Goddelike hand gelei, die belange van die maatskappy waaraan hy behoort. Verder, as gevolg van die feit dat die industriële rewolusie in Engeland plaasgevind het lank voordat dit in enige ander land ter wêreld plaasgevind het, naamlik gedurende die laaste helfte van die 18de eeu, is daar groot klem gelê op vryhandel; voor hierdie tyd, vanaf ongeveer 1500 tot 1750, het die Britse regering en ekonome 'n merkantilistiese beleid voorgestaan, dit is, een waaronder die staat hom ingemeng het met die ekonomiese bedrywighede van sy burgers met die doel om homself ekonomies te versterk; in Frankryk is hierdie beleid Colbertisme genoem, en in Duitsland kameralisme. Hierdie beleid is nie alleen deur beskermende tariewe vir die plaaslike nywerhede uitgevoer nie, maar kolonies moes hul fabrikate van die moederland koop en grondstowwe vir die moederland produseer, die vervoer moes in die skepe van die moederland plaasvind, en die uitbetaling van goud aan die buiteland is streng beheer omdat dit beskou is as die spiere van die oorlog.

'n Verder belangrike trek van die sogenaamde klassieke skool, veral soos aangedui deur David Ricardo in sy Bullion Report (1810), was die opvatting, in die geld- en bankwese, van inflasie en deflasie: met ander woorde, as papiergeld vinnig vermenigvuldig teenoor die goudreserwes van 'n land, soos in Brittanje tydens die Napoleontiese oorloë, dan moet die papiergeld drasties verminder word ten einde 'n beter verhouding tussen die goudbasis 
en die krediet-superstruktuur teweeg te bring. Dit het gewoonlik tot genadelose depressies gelei en al die ellende wat daarmee gepaard gaan. Hierdie gevoellose en onnosele beleid het dwarsdeur die 19de eeu hoogty gevier, en dit is slegs na die tweede wêreldoorlog dat die finansiële leiers van die groot Westerse lande begin besef het dat kommunisme nie met depressies en werkloosheid kan beveg word nie. Verder het die ontdekking van goud in Kalifornië, Australië en die Transvaal, gedurende die tweede helfte van die 19de eeu, dit moontlik gemaak vir Engeland, destyds die leidende land van die wêreld op ekonomiese en finansiële gebied, om die ellendige dalende ekonomiese kurwe van die eerste helfte van die eeu weer in 'n stygende rigting te stuur: meer krediet kon geskep word teenoor 'n groeiende goudbasis.

Die drie ekonome wat die Britse klassieke skool van die politieke ekonomie mokerhoue toegedien het, was die Duitse ekonoom, Friedrich List (List het vanf 1825/32 in die Verenigde State van Amerika gewoon en het in 1841 Das Nationale System der Politischen Okonomie uitgebring waarin hy die beskerming van nywerhede by wyse van die invoertarief bepleit het) en die twee Engelse ekonome, John Maynard Keynes en J. A. Hobson. Die verste wat 'n klassieke ekonoom gegaan het, wat betref inmenging in die heiligdom van die sogenaamde ekonomiese vryheid, was John Stuart Mill; hy het die standpunt ingeneem dat dit vir die staat geoorloof is om 'n jong industrie tydelik te beskerm totdat hy op die been is (die sogenaamde ,,infant industry"-argument).

Toe die Verenigde State van Amerika op groot skaal industriëel ontwikkel het na die Burger-oorlog vanaf 1861 tot 1865 , het hy nie gehuiwer om sy nywerhede met die meeste beslistheid te beskerm nie, en Duitsland het dieselfde gedoen na 1879. En dit is gedurende die laaste kwart van die 19de eeu dat sekere elemente in Brittanje begin hunker het na 'n nuwe vorm van merkantilisme vir die beskerming van hulle markte deur middel van Britse voorkeur. Een van die leidende manne in hierdie beweging was die Birminghamse staalkoning en Britse politikus, Joseph Chamberlain, en die man wat Suid-Afrika in 1903 belas het met hierdie nuwe vorm van die merkantilisme was lord Milner, die verteenwoordiger van Chamberlain.

Hierdie inbreuk op die geroemde vryhandelsbeleid van Brittanje is egter met veel omsigtigheid toegelaat omdat laasgenoemde sy voedsel en grondstowwe tot 'n groot mate moes invoer. Tot na die eerste wêreldoorlog dus, het Brittanje vierkantig teen voorkeur vir koloniale produkte in sy markte gestaan omdat dit alleen deur invoertariewe kon gedoen word en dit het 'n hoër lewenskoste beteken, iets wat op sy beurt vir Brittanje 
as uitvoerland onwenslik was; hy was egter gereed en begerig om beskerming deur middel van voorkeurtariewe op sy fabrikate in koloniale markte te ontvang-iets waarin hy geslaag het eerste in Kanada, ${ }^{*}$ daarna in SuidAfrika (1903) en later in Australië en Nu-Seeland. Brittanje volg dus 'n tweeslagtige handelsbeleid: die kolonies kan tariewe invoer met die doel, o.a., om hom voorkeur te gee omdat hy markte vir sy fabrikate nodig het ten einde grondstowwe en voedsel te kan koop en geld in die ryk en buiteland te belê (laasgenoemde ' $n$ bron van onsigbare inkomste), dog wat $s y$ weltanschauung op die gebied van die handel betref, is die standpunt dat die handel vry moet wees. Brittanje onderneem dus liewer om 'n kwota in sy mark aan dominiale of koloniale produkte toe te staan as om 'n stywe tarief in te voer en voorkeur aan sy kolonies en mededominiums te gee by wyse van ' $n$ vermindering in daardie tarief.

Die beleid van ' $n$ ander groot industriële land-die grootste in die wêreld-naamlik die Verenigde State van Amerika, is baie meer direk en ondubbelsinnig. Hy huiwer nie om 'n drastiese beskermingsbeleid toe te pas as hy dit goeddink nie, en daar was 'n tyd toe sy buitelandse handel deur middel van voorwaardelike meesbegunstigde-nasie-verdrae aangemoedig is op 'n quid pro quo-basis: tariefkonsessies is toegestaan aan vreemde nasies alleen vir gelykwaardige konsessies. En al sou die Verenigde State van Amerika by ' $n$ organisasie soos G.A.T.T. aansluit, en ook probeer om die wêreldhandel so vry as moontlik te maak, huiwer hy nooit om 'n beskermende tarief in te voer as dit nodig is vir 'n Amerikaanse nywerheid nie: sy buitelandse handel bevat sowat 5 persent van sy totale handel, en daar word nie eers baie aandag gewy aan die vraag of ander lande aan hom kan verkoop ten einde van hom te kan koop nie. Indien nodig, stig hy tak-fabrieke in die buiteland. Sy nywerheid is in elk geval op so 'n doeltreffende, grootskaalse basis georganiseer dat hy kan meeding in die meeste buitelandse markte.

Waar die Britte dus aan die een kant handelsdiskriminasie in die vorm van Britse voorkeur goedkeur, omdat dit hulle pas, steun hulle aan die ander kant vryhandel sover moontlik vir die res van die wêreld, ook vir die Gemenebes en die Ryk as 'n basiese beleid. Hierdie beleid is nadelig vir die Unie omdat, eerstens, lande buitekant die Ryk en Gemenebes voorkeur as diskriminasie beskou, en omdat, tweedens, die Unie se industrieë veels te jonk en klein is om 'n vryhandelsbeleid, of selfs 'n G.A.T.T.-beleid, te onder-

\footnotetext{
* Te wyte aan die gewetenswruegings van die Kanadese wat hul „national policy" van
} nywerheidsbeskerming onder sir John MacDonald op onverbiddelike wyse toegepas het. 
steun. Sterk industrielande kan maklik vryhandel bepleit, omdat hulle industrieë op groot genoeg skaal georganiseer is om sowel in die binneland as in die buiteland te kompeteer: vir 'n klein en jong land is dit eenvoudig laf om so 'n beleid te volg.

Afrikaanse ekonome wat dus dweep met vryheid in die handel, wat die vertroosting van grootmoedigheid vind in die G.A.T.T.-doolhof, vergeet dat, terwyl ons in die twintiger jare nog te kampe gehad het met 'n geweldige sogenaamde armblankedom en vyfdelige rapporte (gefinansier deur 'n Amerikaanse staalmagnaat) oor die saak, daardie ellendige woord, ,armblanke", vandag nooit meer gehoor word nie, omdat die tariefwet van 1925 geen doekies omgedraai het nie, beide wat betref die beskerming van ons eie nywerhede, en die vermindering of verwydering van voorkeur, aan enige nasie in ons tarief: 'n mens kan nie vreemdeling met die een hand help om jou mark binne te dring nie, en met die ander hand probeer om die mark vir jou eie produkte te beskerm nie. Dit is om hierdie rede dat ek as ekonomiese deskundige nog steeds 'n onwrikbare opponent van 'n onverbiddelike multilaterale handelsstelsel was, en nie kon sien hoe 'n bilaterale, of tweesydige, handelsooreenkoms, ten einde die land se buitelandse handel op planmatige wyse aan te moedig, nou juis direk uit die verderf afkomstig is nie. Dog die goeie ekonomiese fondamente wat in die twintiger jare gelê is, is gevaarlik ondermyn op die Ottawa-konferensie in Augustus 1932-een van die ongelukkigste jare in die geskiedenis van die Afrikaner.

En wat die opvatting betref dat privaat inisiatief (die onverbiddelike indiwidualisme van die ou klassieke skool van Britse politieke ekonomie) uit die hemel is, terwyl enige staatsinisiateif uit die ander plek is, moet ons oppas dat ons nie 'n droom met die werklikheid verwar nie. Ons moet nie toelaat dat ons oorgeërfde en ingevoerde ekonomiese idees ons tot nasionale selfmoord of stagnasie lei nie. Ons moet probeer om ons land se probleme te sien in die lig van ons land se behoeftes. Wat is hierdie behoeftes?

Die eerste behoefte is natuurlik die behoud van die volk. Op materiële gebied kan dit bewerkstellig word deur die ontwikkeling van die ekonomiese rykdom van die land-'n rykdom wat in die verlede tot afguns en bloedvergieting gelei het, en vandag tot roekelose swartsmeerdery van die Afrikaner. Omdat die indiwiduele Afrikaner in die verlede, as stoere pionier, in 'n onbeskaafde land te midde van barbare moes optree, het die sekondêre werk, verbonde aan die ekonomiese ontwikkeling van ons natuurlike hulpbronne, geval in die hande van persone wat dit in beskaafde Europa of Brittanje geleer het en 'n Goddelike kans gekry het om, met behulp van hulle 
oorsese konneksies, hulleself ekonomies te verryk sonder groot persoonlike opofferings-persone wat vandag in baie gevalle klippe gooi teen die pionier en sy afstammelinge se toewyding aan hulle geboorteland, omdat 'n mens alleen dit kan innig werklik liefhê waarvoor jy gely het. Ten einde die pioniers se afstammelinge ten minste ' $n$ kans te gee om ook hulle regmatige rol te speel in die ekonomiese ontwikkeling van die land, moet die regering, veral as hy die pionier en sy nageslag verteenwoordig, nie skroom om die inisiatief te neem waar die indiwidu nie die praktiese kennis of die kapitaal besit om uiters nodige ekonomiese ontginningswerk aan te pak nie. Waar, byvoorbeeld, het die afstammeling van die Suid-Afrikaanse pionier sy talente ten volle kon ontwikkel op die gebied van die ekonomiese ontwikkeling van die land? Dáár waar die staat die inisiatief geneem het; anders sou die pioniers se nakomelinge maar moes aanhou om die korsies te eet wat val van die tafel van die oorsese baas van kapitaal en kennis. Hier wil ek graag noem ondernemings soos die Suid-Afrikaanse Spoorweë, Yskor, N.O.K., K.O.P., Foskor, Sasol, die Uitsaaikorporasie, Escom, en so meer. Professor W. Arthur Lewis sê in sy skitterende werk, The Theory of Economic Growth (1956), bladsy 79: "Individualism is not necessarily the quickest road to economic growth. Collective action is also necessary, and in certain circumstances may even have quicker results. Collective action in the form of Government action is necessary even if only to supplement private action. Government have extensive functions in promoting economic development. These range, even in private enterprise economies, from such obvious functions as maintaining roads or promoting research, to more sophisticated functions such as underwriting new enterprises or providing capital to private business. The rôle of Government depends to some extent on the quantity and quality of private entrepreneurship; the less able the individuals to pioneer, the greater the burden that falls upon an enterprising public service."

In hierdie verband moet met nadruk verklaar word dat, deur die inisiatief van 'n simpatieke en patriotiese regering, die volk dus nie net geestelik verryk word nie dog, deur nuwe ondernemings te skep, die volk op ekonomiese gebied baie vinniger verryk word as deur die opgaar van al die spaarpennies in die wêreld deur die privaat indiwidu: wat meer is, in die moderne wêreld is daar maar bra min kans om 'n saak op klein skaal te begin en sukses te verwag.

Hierdie afsku vir inisiatief deur die staat het ons ook ingedrink uit die geestelike nalatenskap van die Britse klassieke skool van ekonome, wie se 
werk ' $n$ verheerliking was van die Britse kapitalistiese indiwidualisme wat deur die Britse nywerheidsontwikkeling en imperialistiese veroweringstogte te voorskyn gebring is. As 'n mens dus 'n Afrikaner, met sy beperkte bankbalans en sy beperkte handels- en nywerheidskonneksies, somtyds oor die voortreflikheid van privaat onderneming op onkompromiterende wyse hoor uitwei, dan kry jy hom jammer diep in jou hart; en as 'n mens somtyds 'n Afrikaner wat sy vooruitgang honderd persent aan staatsinisiatief te danke het, hoor uitwei oor die onwenslikheid daarvan dat die staat ,sy neus in privaat besigheid steek”, dan kan 'n mens alleen sê: „Vader vergewe hom dit, want hy weet nie wat hy doen nie".

Voordat ek aangaan om aan te toon hoe ons idees oor bank- en geldwese ook ' $n$ honderd persent gekleur is deur wat ons uit Brittanje gekry hethoe ons eenvoudig aanneem dat wat Brittanje pas ook ons moet pas-wil ek net aantoon hoe ons ekonomie ook in die algemeen verskil van die van Brittanje-'n feit wat ons glad nie genoeg voor oë hou nie. Ek refereer na die feit dat ons 'n magtige goudproduserende onderneming in ons land het. Goud is 'n produk met 'n vasgestelde prys-altans oor lang periodes -en dus as die ekonomiese lewe van die res van die land floreer, dan styg die produksiekoste van goud en kla die mynbase; as die res van die land se ekonomie 'n swaar tyd deurmaak-lae pryse, lae lone, werkloosheid, ens.dan floreer die goudmyne, soos byvoorbeeld in 1932. Enige poging dus om krediet in te kort, die ekonomiese posisie te ,konsolideer” en te ,stabiliseer"-wat eenvoudig op agteruitgang uitloop, omdat iets wat nie beweeg nie sterf-sal deur die goudindustrie verwelkom word. In hierdie verband is die groep wat aan die wenkant uitkom hulle wat die nodige kennis en die beste propagandamiddels besit.

In die geval van bank- en geldwese werk die bande baie meer subtiel, omdat die publiek 'n beter begrip van die handel en nywerheid het as van bank- en geldwese; laasgenoemde word as 'n toewnaarskuns beskou wat in die hande van die towenaars, of bankiers, gelaat moet word-dit ondanks die feit dat bankwese soos 'n worsmasjien gestandardiseer is.

In die ou Kaapse dae het daar 'n hele boel distriksbanke ontstaan, en dit is ' $n$ plesier om te sien hoe die redakteur van die ou Commercial Advertiser in die middel van die 19de eeu homself op hoogte gebring het van die beweging in sy verhouding tot die openbare welvaart. Kort daarna (1861) het die eerste sogenaamde imperiale bank, die Standard Bank of S.A., Ltd., sy verskyning op die toneel gemaak en, in die plek van distriksbanke, wat die ekonomiese aangeleenthede van hul distrikte begryp het, het 
daar 'n takbankstelsel gekom met 'n beleid wat 'n hoof kantoor van iewers elders af neergelê het.

Die tweede imperiale bank, naamlik die Nasionale Bank van S.A. Beperk, ${ }^{*}$ het sy oorsprong gehad in die bank wat die ou Vrystaatse Republiek gestig het in 1891 met die $£ 90,000$ wat die Britse Regering aan hom uitbetaal het na die Keate-arbitrasietoekenning in verband met die Kimberleyse diamantvelde. Hierdie bank is later ingelyf met die Bank van Natal en, in die begin van die twintiger jare** het die Britse bank, Barclay's, die Nasionale Bank van S.A. uitgekoop. Die Unie was toe geseën met twee imperiale takbankstelsels, De Nederlandsche Bank van Zuid-Afrika Beperk en die South African Reserve Bank: éen enkele distriskbank, die Distriksbank van Stellenbosch, het oorgebly.

Die S.A. Reserwebank het sy geboorte gehad na aanleiding van die werk van 'n parlementêre gekose komitee in 1920 in verband met die verbod op die uitvoer van muntgoud. Die algemene onkunde wat daar destyds in Suid-Afrika bestaan het omtrent bank- en geldkwessies was kolossaal, en wyle prof. Edwin Cannan, die destydse dekaan van Britse ekonome, het in die Economic Journal van Desember, 1920, gesê dat Suid-Afrika se goudbeleid hom laat dink aan ,die dorp se skoenmaker wat saam met sy familie kaalvoet in die strate loop om te toon hoe sleg dit is om skoene te dra". Hierdie geleentheid is destyds gebruik deur mnr. Henry Strakosch om sy idees omtrent 'n sentrale reserwebank op die gekose komitee af te druk.

Dit was net na die eerste wêreldoorlog en dit was moeilik om Britse korttermynlenings in die vorm van skatkiswissels te plaas. Daar is toe 'n plan ontwerp om 'n ketting van sentrale reserwebanke in die lewe te roep dwarsdeur die Britse Ryk (dié deel wat na 1926 die Britse Gemenebes van Nasies geword het), banke wat note kan uitgee teen die sekuriteit van goud, eersteklas handelswissels en Britse skatkiswissels. Suid-Afrika was die eerste Britse kolonie om vir hierdie plan te val, en mnr. Henry Strakosch is tot ridder geslaan. (Kort hierna, in 1923, is mnr. Wm. MacIntosh, L.V. vir Port Elizabeth-Noord, ook tot ridder geslaan vir die werk wat hy verrig het in verband met die Bankwet (1920) Wysigingswet van daardie jaar). Kanada het heelwat later sy sentrale bank gekry, so het Nu-Seeland, terwyl Australië verkies het om met sy Commonwealth Bank, 'n staatsbank, aan te gaan met die oog, onder andere, op immigrasie en nedersetting. Die

\footnotetext{
* 1911-1 25 .

**1925.
} 
beleid van imperiale bankwese is so ernstig opgeneem in Londen-ek onthou nog goed die sending van mnr. J. F. Darling in 1923 in hierdie verband, want ek het hom skerp gekritiseer-dat, toe 'n konstitusie vir Indië in 1935 opgetrek is deur die toentertydse Britse konserwatiewe regering, hoofstuk $\mathrm{XV}$ daarvan aan die stigting van 'n sentrale reserwebank gewy is.

Suid-Afrika het toe die onderskeiding gehad dat hy 'n sentrale reserwebank in 1920 gekry het vir sy twee groot banke. 'n Mens kan verstaan dat die Verenigde State van Amerika 'n reserwebankstelsel moes invoer in 1914 want die Verenigde State van Amerika het destyds, as ek goed onthou, sowat 30,000 indiwiduele banke gehad, en sentrale beheer het nodig geword as die land chaos in tye van finansiële krisis wou vryspring. Die hoofrekenmeester van die Bank van Engeland, mnr, W. H. Clegg, is as die eerste goewerneur van die bank aangestel, en hy het die imperiale fondamente goed gelê.

As deskundige op hierdie gebied kan ek natuurlik veel sê oor hierdie onderwerp-byvoorbeeld hoe die Reserwebank in 1931, ondanks die feit dat dit nie 'n staatsbank was nie, sy hele reserwefonds en die helfte van sy kapitaal verloor het op sy Londense beleggings; maar die tyd is kort en al wat ek wil beklemtoon is dat Suid-Afrika nie 'n sentrale reserwebank in 1920 nodig gehad het nie, dog meer kompetisie in sy bankstelsel. Aangesien dit moeilik is vir ' $n$ nuwe bank om sy voete te kry in die teenwoordigheid van die twee sterk imperiale banke, en ons dus ons bewondering moet uitspreek vir ons te vroeg heengegane vriend, mnr, J. J. Bosman, met sy Volkskas, Beperk, het ek steeds gevoel vir meer as 33 jaar dat, wat Suid-Afrika nodig gehad het, en vandag nodig het, was en is 'n staatsbank, en ek onthou goed hoe ek mnr. Bosman ontmoedig het in 1933 in verband met sy idee om 'n nuwe kommersiële bank te stig; my idee was dat ons direk na die groot saak moes strewe sodat ons vir Suid-Afrika kon doen wat die Commonwealth Bank vir Australië gedoen het, en die Riksbank, die oudste sentralebank (toevallig 'n staatsbank) in die wêreld, vir Swede gedoen het. Selfs die ou Vrystaat het met sy reeds gemelde $£ 90,000$ 'n staatsbank gestig.

Ek wil nie hier in die meriete of die nie-meriete van 'n staatsbank gaan nie. In 1924, toe mnr. Havenga vir drr. Vissering en Kemmerer na die Unie gekry het om die Regering te adviseer in verband met die wenslikheid al dan nie vir die Unie om terug te keer tot die 1914-goudstandaard, het hy dr. Vissering versoek om 'n spesiale rapport uit te bring oor die wenslikheid al dan nie van 'n staatsbank vir Suid-Afrika. Dit het die doktor met meer as konserwatiewe deeglikheid gedoen--iets wat nie belet het dat ook sy bank, 
die Bank van Nederland, sowat 80 miljoen gulden in September, 1931, op sy Londense beleggings verloor het nie-dieselfde tyd toe ons Reserwebank sy groot verliese gely het. Al wat ek hier wil sê is dat dit verregaande vermetelheid was van Vissering en Clegg om die standpunt in te neem dat, wanneer die skatkis beleid neerlê vir 'n sentralebank in privaat besit dan is alles uit die finansiële hemel, dog as die skatkis beleid neerle vir 'n sentralebank wat deur die staat besit word, dan is alles uit die bose.

Ek gaan uit van die standpunt, en sal met die standpunt na my gra, gaan, dat Suid-Afrika 'n staatsbank nodig het, en nie 'n sentralebank nie wat in die een asem met die onvertroubare skatkis praat, en in die ander asem die publiek probeer wysmaak dat hy met al die wysheid en vertroubaarheid van die privaat inisiatief praat en handel. En, vanaf hierdie punt uitgaande, wil ek as eerste stap vir ons staatsbank aanbeveel die volle gebruikmaking van ons goud.

Wat, sal gevra word, is die verskil tussen die verkoop van ons goud in Londen op die sogenaamde vrye goudmark, of aan ons reserwebank? Die antwoord is dat, deur ons goud op die Londense vrye mark te verkoop, ons krediet kry in terme van sterling, of Britse papierponde, tot 'n bedrag wat gelykstaan aan die getal onse goud wat ons uitstuur na daardie mark vermenigvuldig met plus minus $£ 12$ 10s. Od.-met ander woorde, ons verkoop ons goud soos ons ons mielies en velle verkoop, terwyl die eintlike rol van goud die van kredietbasis is: met ons Britse papierpondkrediet kan ons niks meer doen as met die getal papierponde waaruit dit bestaan nie, dog op die basis van elke papierpond se goud wat, byvoorbeeld, deur die Bank van Engeland gekoop word op die sogenaamde Londense vrye goudmark, kan die Bank die skepping van $£ 20$ tot $£ 25$ se krediet regverdig. Vir Londen, wat nie alleen 'n finansiële wêreldsentrum is nie, maar wat ook bankier van die sterling bloc is, is dit uiters noodsaaklik om seker te maak dat hy goud in die hande kry, want al neem goud vandag nie aktief deel in handelstransaksies nie, werk dit soos 'n katalisator in 'n chemiese reaksie: terwyl dit nie deelneem aan die transaksie (of reaksie) nie, vergemaklik dit egter die transaksie (of reaksie). Die vertroue in goud is nog daar en 'n land wat sy ongunstige betalingsbalans in klinkende goudmunt kan betaal, kan alleen die vertroue win van die buitewêreld-afgesien van die krediet-potensiaal wat deur so 'n beleid geskep word terwyl die goud deur die boeke van die sentralebank gaan.

Ten einde seker te maak dat hy elke jaar 'n sekere hoeveelheid van ons goudproduksie in die hande kry, of sy betalingsbalans met Suid-Afrika dit 
nou regverdig of nie, het Brittanje 'n ooreenkoms met ons skatkis aangegaan, ek meen dit was in 1951, waaronder die Unie onderneem het om elke jaar ten minste 4 miljoen onse goud (of $£ 50,000,000$ se waarde aan goud) aan die Britse skatkis te besorg. (By 'n vorige geleentheid, in 1948, het die Unie-skatkis 'n goudlening van $£ 80,000,000$ aan Brittanje gemaak omdat laasgenoemde dit dringend nodig gehad het en nie anders kon kry nie). Hoe werk hierdie goudooreenkoms?

Onder die ooreenkoms met die Britse skatkis betaal die Unie vir sy invoer uit die dollargebied met dollars, wat ons verdien het, en/of met goud, terwyl hy vir sy invoer uit die nie-dollar-gebied met sterling betaal. Wanneer Suid-Afrika se betalings in sterling die hoeveelheid sterling oortref waaroor hy beskik as gevolg van-

(1) uitvoer na die sterlinggebied,

(2) die uitvloei van Britse kapitaal na Suid-Afrika, en

(3) bedrae van sterling in die Unie se besit waarteen getrek kan word, dan word die ongunstige balans vereffen deur 'n besending van goud na Londen. Hierdie goud, volgens die ooreenkoms van 1951 tussen die Britse Skatkis en ons Skatkis, sou onder geen omstandighede minder as $£ 50,000,000$ per jaar beloop het nie, en kon ook meer gewees het as Brittanje 'n redelike gedeelte van ons mark gekry het.

Nou spreek dit vanself dat, as die hoeveelheid Britse kapitaal wat na Suid-Afrika vloei, minder is, dan, ceteris paribus, is die hoeveelheid goud groter wat ons na Londen moet oordra-iets wat die sterling bloc, of liewers, sy bankier, Londen, uitstekend te pas kom as Butler se sterlinginwisselbaarheidsbeleid moet deurgevoer word, en as Londen die eise van die sterling bloc teen hom wil nakom. Oor hierdie punt sê die bekende Londense ekonomiese tydskrif, The Economist van 24 Oktober, 1953, die volgende in 'n gesaghebbende artikel:

„During the past nine months, they (the South African sterling holdings) have fallen from just under $£ 60,000,000$, to just under $£ 25,000,000$; concurrently, the Union's total gold and foreign exchange holdings have fallen from $£ 129,000,000$, to just under $£ 94,000,000$. The total capital inflow in the first six months of this year was only $£ 14,000,000$, compared with the peak inflow of $£ 182,000,000$-most of it sterling-in £947, before Dr. Malan became Prime Minister. Thus, unless (for some at present unforeseeable reason) capital should again begin to move to the Union on a heavy scale, South Africa will 
almost certainly have to meet the greater part of its non-dollar deficit by the transfer to London of some of its newly-mined gold."*

Sou, onder hierdie omstandighede, mnr. Butler of enige ander kanselier van die Britse Skatkis wat die belegging van Britse kapitaal beheer, die uitvloei van Britse kapitaal na Suid-Afrika anmoedig? Natuurlik nie! Geen wonder nie dat mnr. Butler, toe hy nog kanselier van die Britse Skatkis was, uit sy pad gegaan het om vir mnr. Havenga te flikvlooi: „Not one of my colleagues in the sterling area has been of more assistance to this country than Mr. Havenga, the South African Minister of Finance," het hy op 6 November, 1953, in the Britse Laerhuis gesê. En 'n mens kan dit verstaan as jy in aanmerking neem hoe die sekerhied dat hy Suid-Afrikaanse goud in die hande kan kry, vir Brittanje help om nie alleen sterling teen die dollar te versterk nie, maar om sy „partnership"-beleid in die Afrikaanse kolonies uit te voer, waar miljoene nou belê word as teenwig vir die Amerikaanse belangstelling in die grondstowwe van die Afrikaanse vasteland. Bietjie meer as twee jaar gelede nog het mnr. Gardner Cowles, 'n belangrike Amerikaanse koerantman, 'n onderhoud aan die „Star" (sien „The Star” 14 Januarie 1954) toegestaan, waarin hy nadruk gelê het op die Amerikaanse belangstelling in Afrikaanse grondstowwe: dit het hy uitgelaat na aanleiding van 'n bitter aanval op die Regering se apartheidsbeleid (,,apartheidism", soos hy dit genoem het). Na die Sydney-konferensie nog het MacIntyre, die Minister van Finansies van die Sentraal-Afrikaanse Federasie, gesê dat hy op $£ 120,000,000$ by die konferensie aangedring het, en 'n simpatieke gehoor gekry het, terwyl Butler hom die kompliment gemaak het dat hy, MacIntyre, die jongste Minister van Finansies van die sterling bloc, die meeste „commonsense" op die Sydney-Konferensie gepraat het.

En dan hoor ons ad nauseam dat die geweldige vermindering van Britse kapitaalbelegging in die Unie te wyte is aan gebrek aan vertroue by die Britse geldbelêer in die Nasionale Party-Regering: wat 'n kwessie is van Britse (en Amerikaanse) ekonomiese beleid so helder soos kristal, word gebruik om die Nasionale Party-Regering aan te val en die Suid-Afrikaanse publiek te verwar. Ons vorige Eerste Minister moes na Londen gaan op sy oudag om te toon dat hy darem 'n beskaafde mens is, en mnr. Havenga het 'n spesiale radio-praatjie oor apartheid vanuit Londen uitgesaai (30 November 1952) om die Britse geldbelêer gerus te stel, huisvrouens het aangebied om hulle huise oop te stel aan oorsese joernaliste en ander besoekers aan Suid-

\footnotetext{
* Kursivering van my.
} 
Afrika om laasgenoemde lui te oortuig dat ons darem nie sulke slegte mense is nie, en die Opposisie was so bekommerd oor die geweldige vermindering in die toevloei van Britse kapitaal na Suid-Afrika dat hulle op kwalik verhole manier te kenne gegee het dat 'n koalisie-regering die posisie sou red! Voorwaar, as die saak nie so ernstig was nie dan kon 'n mens daaroor gaan sit en lag!

Dog die saak is baie ernstig, en as ons nie betyds besef dat die oorsaak van die hele gedoente van ekonomiese aard is nie, mag ons nog baie donker dae tegemoet gaan. Die grondstowwevoorrade van die aardbol word skaarser namate nywerheidsontwikkeling en die bevolkingsgroei toeneem. Die enigste vasteland wat nog onontgonne is en waar daar miljoene potensiële nywerheidswerkers, landbouwerkers en mynwerkers is, is die Vasteland van Afrika. Soos hierbo aangetoon, het Brittanje en Amerika alreeds hul oog op hierdie gedeelte van die aardbol. Wat is dus meer natuurliker, met die oog op die groot rykdom wat binne Suid-Afrika se grense val, vir die groot kapitaalmagte van Amerika en Brittanje as om die houding in te neem: „Waarom moet ons toesien dat 'n blanke bevolking nie veel groter as die van een van ons groot stede soveel rykdom kontroleer? Ons het die goeie wil nodig van die honderde miljoene gekleurdes binne en buite Afrika, die paar honderd duisend blankes benoorde die Limpopo kan tog nooit die politieke baas daar bly nie, en ons wil die ekonomiese baas daar wees vir baie dekades. Waarom sal ons nie die blanke bevolking van Suid-Afrika as die swart skaap aan die wêreld voorhou nie onder die voorwendsel dat ons die gekleurde man wil help?" Die feit dat ons die enigste beskaafde volk is wat nog ooit 'n vaste en blywende nedersetting in onbeskaafde Afrika daargestel het, tel nie by hierdie mense nie, en treffend is dit dat op Maandag, 27 Augustus, die New York Times en die Washington Post 'n identieke aanval op Suid-Afrika oor sy rassebeleid gemaak het, gevolg deur die Boston Globe die dag daarna.

As my standpunt reg is dan sal dit vir Suid-Afrika niks help om duisende inligtingsbeamptes die wêreld in te stuur om ons standpunt te stel nie. Die swartsmeerders sal heerlik in hulle mou vir ons lag. Nee, ons moet aanval: ons moet aan die wêreld in onomwonde taal vertel wat agter die groot belangstelling in die swartman skuil. Verder moet ons nasionaal-voelende of patriotiese Afrikaners ons afvra waarom hierdie beweging so vernynig geword het na 1948: net soos in 1899-1902 gaan die stryd nie oor die hondjie (stemreg) nie, maar om die halsbandjie (goud en ander rykdom). 
Maar om tot Butler terug te keer: hy het baie verder as bogemelde $£ 50,000,000$ se goud gegaan. Op die konferensie van Eerste Ministers van die Gemenebes wat in Desember, 1952, in Londen gehou is, is besluit dat dit belangrik is dat sterling weer sy volle rol sal speel as ruilmiddel in die handel en wisselkoers van die wêreld. Hierdie groot ideaal kon egter alleen bereik word as Brittanje daarin kon slaag om sterling sonder enige beperkings inwisselbaar te mak met alle ander geldeenhede. Dit, op sy beurt, het ingrypende stappe dwarsdeur die Gemenebes en die Ryk vereis, stappe wat in 1952 begin het met goedkeuring van die Konferensie van Eerste Ministers, en wat finaal beklink is op die Sydney-Konferensie van Ministers van Finansies in Januarie, 1954. Aangesien die stappe hul doel nie kon bereik sonder ekonomiese leed nie, moes dit in mooi woorde bedek word, net soos 'n purgeermiddel somtyds in 'n suikeromhulsel weggesteek word. Die omhulsel van die ekonomiese afdryfmiddel is gevind in die woord „konsolidasie" (ons het te vinnig gegaan en moes die remme aandraai) en die inhoud van die purgeermiddel het onder andere uit die volgende bestaan:

(1) die beperking van kapitaaluitgawe op sogenaamde nie-essensiële ondernemings en ondernemings van minder dringende aard;

(2) die beheer oor die aangaan van openbare lenings;

(3) die inkorting van konsumpsie deur middel van belastings;

(4) 'n ,,versoek" aan die handelsbanke om nie krediet vir sogenaamde „,nie-essemsiële" doeleindes te verskaf nie; en

(5) stappe om die likwiditeitsverhoudings van die banke strenger te maak.

Die pil is verder verguld deur mnr. Havenga se verklaring in Sydney op 15 Januarie 1954, dat, ,die doelwit van die konferensie van Ministers van Finansies van die sterling bloc was om die lewensstandaard van die volkere binne daardie area te verhoog", terwyl Butler op Sondagaand, 17 Januarie, 1954, verklaar het dat ,hul besluite die geluk van die komende geslagte sou verseker".

Dog hierdie samewerking van die Ministers van Finansies van die sterling bloc om sterling te versterk wat Butler op die Sydney-Konferensie bereik het, was 'n bagatel in vergelyking met die heropening, na 15 jaar, van die sogenaamde vrye mark vir goud in Londen-'n stelsel waaronder die bemarking van feitlik al ons goud oorhandig word aan vyf of ses goudmakelaars onder leiding van Rothschild--teen 'n kommissie natuurlik, en binne die perke van die wisselkoersskommelings tussen Londen en $\mathrm{Nu}$-York. Op 
24 Maart, 1954, het ek dus in die Star (Johannesburg) die mening uitgespreek dat die stigting van die sogenaamde vrye goudmark in Londen nie tot ' $n$ verhoging in die prys van goud sou lei nie en het op 14 April 'n afskrif van my brief aan Sy Edele die Eerste Minister gestuur.

Hier volg Die Vaderland van 11 Mei, 1954, se rapport oor mnr. Havenga se verklaring in die Volksraad oor die saak op die vorige dag:

„Die goudmark is met die Britse minister van finansies in Sydney bespreek en die Britse minister het ander dominiums genader. Hy (Havenga) meen dat die Unie die regte ding gedoen het deur steun te verleen aan die heropening van die goudmark. 'n Sekere hoeveelheid goud is (voorheen) aan belanghebbende liggame gestuur, maar vandag word hierdie verkope in Londen gesentraliseer. Enigiemand wat goud nodig het, moet dit op die Londense mark gaan koop. Op die wyse word die mededinging verhoog en dit kan slegs tot voordeel van die Unie se goudnywerheid lei." (Met ander woorde, Havenga se argument het die indruk verwek dat sy nuwe ooreenkoms met Butler tot 'n hoër, prys van goud sal lei as gevolg van die ,verhoogde mededinging" en sy blad, Die Vaderland, het 'n dienooreenkomstige hooflyn gehad na aanleiding van die nuwe plan.)

Hier volg nou verder wat die gesaghebbende Britse blad, The Economist, van 12 Junie, 1954, oor die saak te sê het:

„Almost from the moment of its reopening, the London gold market re-acquired its previous position as the premier centre of the world for dealing in this metal. It is a genuine two-way market in which the bulk of the Commonwealth production of gold* is now sold and where a large part of the world's demand for free gold is attracted by the exceptionally close rates that dealers quote.

Some fears were expressed at the outset that sterling might be damaged by permitting quotations for gold that might depart from the official sterling parity. But the price quoted for gold in London has steadfastly remained below the mint parity of 250s. per fine ounce, so that in fact no such damage has been done.

Instead, .... by greatly extending the scope of London's facilities as an international financial centre, the gold market has made an important

\footnotetext{
* Australië en Kanada was natuurlik nie gereed om elke ons goud deur hul sentrale bankø na Londen te kanaliseer nie.
} 
contribution to the strength of sterling and so, indirectly, to the goal of (sterling) convertibility".*

Onder die kapitalistiese stelsel is goud die basis van kredietskepping en kan daar, in die teenwoordigheid van 'n sentralebank, vyf-en-twintig pond krediet geskep word op 'n goudbasis van een pond. Hoe sterker dus die goudbasis van 'n land, hoe sterker is die kredietverskaffingsmoontlikhede van so 'n land en hoe hoër is sy internasionale kredietstatus.

Geen wonder die hart van 'n wêreldryk het onverbiddelik geagiteer totdat hy in 1899 sy militêre mag teen die Transvaal kon gebruik ten einde seker van die goud van die Witwatersrand te maak nie.

Soos alreeds gesê, in die ou merkantilistiese tyd, toe goud beskou is as die spiere van die oorlog, is handelaars wat goud sonder verlof van die staat die land uitgestuur het, met die dood gestraf. Agter hierdie fanatieke strewe om goud te beheer, skuil daar die drang van self bevordering, van selfbehoud. Die land wat dan ook die beste gebruik van goud gemaak het, naamlik Engeland, die skepper van die goudstandaard, het nie alleen 'n wêreldryk op politieke gebied geword nie, maar het 'n reus geword op die gebied van die wêreldhandel, en het soveel skatte vir sy mense ingesamel dat daardie klein eilandjie, na twee vernielende wêreldoorloë nog 'n wêreldfaktor is wat die geldmag betref. Die pond sterling was sinoniem met die goudstandaard. Die pond sterling moes hoog gehou word: daarvoor is alles opgeoffer want ,England pays its debts”. „Sound currency” was die wagwoord, net soos vryhandel die wagwoord van Engeland geword het nadat hy 'n wêreldfaktor geword het op die gebied van die internasionale handel en die fabriekwese. Na elke oorlog en sy inflasie, dus, was die wagwoord deflasie: terug tot die voor-oorlogse goudstandaard, wat die koste ook al mag wees. Die imperiale belange op die gebied van die politiek en die handel het dit vereis. As hierdie beleid die grootste ellende vir die werkende massas beteken het, en vir diegene wat nie 'n groot bankrekening gehad het nie, dan het dit nie daarop aangekom nie: die belange van die geldmag het die eerste gekom. (Vandag, natuurlik, kan die Westerse wêreld nie so hooghartig 'n beleid van deflasie na inflasie volg nie, omdat hy nie die kommunisme met werkloosheid kan beveg nie).

Toe Duitsland en die Verenigde State van Amerika die veld van internasionale kompetisie op handelsgebied ingetrek het aan die einde van die neëntiende eeu, en die Britse fabrikante dit opdraend begin kry het, het die aarts-imperialis, Joseph Chamberlain, sy kampanje van Britse voorkeur

* Die beklemtoning is deur my aangebring. 
begin-'n beleid wat sy eie land verwerp het om alombekende redes-'n beleid wat hy, na wapengeweld, die keel van Suid-Afrika kon afdruk.

As 'n Afrikaanse politikus dus pleit vir ,sound currency at all costs", vir ,,vryer of multilaterale wêreldhandel" ten koste van ons eie nywerheidsontwikkeling, en vir Britse voorkeur deur middel van die tarief, dan pleit hy vir belange wat nog steeds lynreg ingedruis het teen die belange van ons eie land. Dan is hy die slagoffer van propaganda wat hy self nie begryp nie. Die Britte begryp goed dat die hemp nader as die broek is: ongelukkig begryp sommige Suid-Afrikaners dit nie.

A. J. BRUWER. 